\title{
Enhanced Production of Alkaline Protease by a Mutant of Bacillus licheniformis N-2 for Dehairing
}

\author{
Muhammad Nadeem $^{1 *}$, Javed Iqbal Qazi ${ }^{2}$ and Shahjahan Baig ${ }^{1}$ \\ ${ }^{I}$ Biotechnology and Food Research Center; PCSIR Laboratories Complex; Lahore-54600; Pakistan. ${ }^{2}$ Department of \\ Zoology; University of the Punjab; Lahore-54590; Pakistan
}

\begin{abstract}
The purpose of the present investigations was to improve the yield of alkaline protease for leather dehairing by subjecting the indigenous proteolytic strain Bacillus licheniformis $\mathrm{N}-2$ to various mutagenic treatments viz. UV irradiations, NTG (N-methyl-N-nitro-N-nitrosoguinidine) and MMS (methyl methane sulfonate). After screening on skim milk agar plates, a total of nine positive mutants were selected for shake flask experiments. Among these, the best proteolytic mutant designated as UV-9 showed 1.4 fold higher alkaline protease activity in preoptimized growth medium than the parent strain. The fermentation profile and kinetic parameters such $u\left(h^{-1}\right), Y_{p / s}, Y_{p / x}, Y_{x / s}, q_{s}, Q_{s}, q_{p}$ and $Q_{p}$ also indicated the superiority of the selected mutant $U V-9$ for alkaline protease production over the parent strain and rest of the mutants. The dehairing capability of mutant UV-9 alkaline protease was analyzed by soaking goat skin pieces for different time intervals (3-15 h) at $40{ }^{\circ} \mathrm{C}$. A complete dehairing without degradation of collagen was achieved after $12 \mathrm{~h}$, indicating its commercial exploitation in leather industry.
\end{abstract}

Key words: Bacillus mutants, mutagenic treatments, alkaline protease, dehairing agent

\section{INTRODUCTION}

Leather is one of the most dynamic sectors, in Pakistan, after cotton and textile industries where almost all the industries use lime and sulphide to remove hairs from hides and skins. Despite making significant contributions to the economy, the leather industry causes sever environment pollution due to the use of various chemicals and release of several detrimental materials (Pvanakrishnan and Dhar, 1986; Meraz et al., 2006). The process of leather processing contributes $80-90 \%$ of the total pollution in the leather industry and generates noxious gases as well as solid waste e.g. hydrogen sulphide and lime (Thanikaivelan et al., 2004). Many cases of deaths have also been reported due to these toxic chemicals (Balasubramanian and Pugalenthi, 2000). Alkaline protease can be used as an alternative to sulphide.

The alkaline protease enables the swelling of hair roots, subsequently attacks hairs follicle protein and then allows easy removal of hairs (Gupta et al., 2002). Microorganisms are attractive source of proteases because of their biochemical diversity and the ease of genetic manipulation. A large proportion of the alkaline proteases are derived from the microorganisms especially from Bacillus strains (Puri et al., 2002; Huang et al., 2003). The amount of protease produced from microorganisms depends on the nature of strains and the composition of the growth medium (Nadeem et al., 2006; Nadeem et al., 2007).

A hyper-productive organism growing on an

* Author for correspondence: mnadeempk@yahoo.com 
economical substrate is the prime need of any fermentation process. Mutation can play an important role in improving the yield of alkaline protease with excellent dehairing effect (Wang et al., 2007). However, many of the proteases with high unit activities have faced failure for successful application because they could not meet the specific requirements of different industrial process. With respect to dehairing protease, the enzyme should exhibit remarkable capabilities of dehairing without damaging the fibrous collagen (Macedo et al., 2005). Considering these facts, the present attempt was made to develop hyperproductive organisms by employing different mutation techniques. The best proteolytic mutant was selected after comprehensive screening study. The alkaline protease produced from a selected mutant was used as dehairing agent against goat skins to assess its potential applications in leather industries.

\section{MATERIALS AND METHODS}

\section{Microorganism and culture maintenance}

Bacillus licheniformis $\mathrm{N}-2$, a wild strain isolated from decaying organic soil sample was used in this study (Nadeem et al., 2007). The culture of $B$. licheniformis $\mathrm{N}-2$ and its mutants were grown on nutrient agar (Oxoid) slants at $37^{\circ} \mathrm{C}$ for $24 \mathrm{~h}$ and then preserved at $4^{\circ} \mathrm{C}$ for one month. The slants were sub-cultured routinely after an interval of 4-5 weeks to revive the culture.

\section{Preparation of cell suspension}

A $24 \mathrm{~h}$ old loopful culture of B. licheniformis $\mathrm{N}-2$ was transferred from slant into $50 \mathrm{~mL}$ nutrient broth (Oxoid) and incubated at $37^{\circ} \mathrm{C}$ for $12 \mathrm{~h}$ at $140 \mathrm{rpm}$ in water bath shaker (Eyela, Japan). After that, $10 \mathrm{~mL}$ of the inoculated broth was centrifuged at $9000 \times \mathrm{g}$ for $10 \mathrm{~min}$ at $4^{\circ} \mathrm{C}$ to separate the cell biomass. The cell biomass pellet was then dissolved in $10 \mathrm{~mL}$ sterilized normal saline under aseptic conditions to prepare cell suspension (approximately $10^{8-10}$ cells $/ \mathrm{mL}$ ) for subsequent experiments.

\section{Mutagenesis by UV treatment}

Various serial dilutions of cell suspension were prepared and the dilution $10^{-7} / \mathrm{mL}$ was distributed into different sterilized glass Petri plates $(2 \mathrm{~mL}$ in each Petri plate). These plates were exposed to UV radiations $(254 \mathrm{~nm})$ for variable time intervals ranging from 5 to $120 \mathrm{~min}$ in UV chamber keeping the distance of UV source fixed at $11.5 \mathrm{~cm}$. After required exposer, the sterilized nutrient agar media (Oxoid) were poured into each Petri plate and the plates were placed in dark for $2 \mathrm{~h}$ to stabilize the nutrient agar medium. Then the plates were incubated at $37^{\circ} \mathrm{C}$ for $48 \mathrm{~h}$ and the $\%$ of survival was calculated over the control (plate was kept aside in dark without UV treatment).

Mutagenesis by NTG ( $N$-methyl- $N$-nitro- $N$ nitrosoguinidine) and MMS (methyl methane sulfonate) treatments

One milliliter of cell suspension was taken in different test tubes. Then $1 \mathrm{~mL}$ each of NTG (1 $\mathrm{mg} / \mathrm{mL})$ and MMS (100 $\mathrm{uL} / \mathrm{mL})$ was added in respective test tube except control. The treated cell suspensions were incubated at $37^{\circ} \mathrm{C}$ for different time intervals $(15-120 \mathrm{~min})$ to determine the survival rate. After required period of treatment, the cells were centrifuged at $9000 \times \mathrm{g}$ for $10 \mathrm{~min}$ at $4^{\circ} \mathrm{C}$, washed with sterilized normal saline twice, diluted and poured into the sterilized Petri plates. After keeping in dark for $2 \mathrm{~h}$, these Petri plate were incubated at $37^{\circ} \mathrm{C}$ for $48 \mathrm{~h}$ and the plates having minimum $\%$ of survival rate over the control (without treatment) were selected for screening of hyper-proteolytic mutants.

\section{Screening of hyper-proteolytic mutants}

After various mutagenic treatments, all the selected isolates were streaked on skim milk agar plates. The skim milk agar medium was composed of (g/L): skim milk (10), peptone (1), sodium chloride (5), and agar (20). The $\mathrm{pH}$ of the medium was adjusted at 10 with $1 \mathrm{~N} \mathrm{HCl} / \mathrm{NaOH}$ before sterilization at $121^{\circ} \mathrm{C}$ for $15 \mathrm{~min}$. The streaked skim milk agar medium plates were incubated at $37^{\circ} \mathrm{C}$ for $24 \mathrm{~h}$ and the isolates exhibiting maximum zone of hydrolysis as compared to wild type were selected for further study.

\section{Enzyme production study}

Shake flask experiments were carried out in 250 $\mathrm{mL}$ Erlenmeyer flasks with $50 \mathrm{~mL}$ of growth media for comparative evaluation of enzyme production by wild stain of $B$. licheniformis $\mathrm{N}-2$ and the selected hyper-proteolytic mutants.

\section{Inoculum preparation}

Inocula were prepared by transferring a loopful of $24 \mathrm{~h}$ old wild type and selected mutant cultures in $50 \mathrm{~mL}$ of inoculum medium comprising of $(\mathrm{g} / \mathrm{L})$ : 
glucose (5), soybean meal (10), $\mathrm{K}_{2} \mathrm{HPO}_{4}$ (5), $\mathrm{MgSO}_{4} \cdot 7 \mathrm{H}_{2} \mathrm{O}(5), \mathrm{NaCl}(0.5)$ and $\mathrm{CaCl}_{2} \cdot 2 \mathrm{H}_{2} \mathrm{O}$ (0.5). The $\mathrm{pH}$ of the inoculum medium was adjusted at 10 before sterilization at $121^{\circ} \mathrm{C}$ for 15 min. The inoculated broths were incubated in water bath shaker (Eyela, Japan) at $140 \mathrm{rpm}$ for 24 $\mathrm{h}$ at $37^{\circ} \mathrm{C}$ for the propagation of bacteria up to $10^{8-10}$ cells $/ \mathrm{mL}$.

\section{Cultivation of the growth medium}

The growth medium contaning $(\mathrm{g} / \mathrm{L})$ : glucose $(10)$, soybean meal (10), $\mathrm{K}_{2} \mathrm{HPO}_{4}(5), \mathrm{MgSO}_{4} \cdot 7 \mathrm{H}_{2} \mathrm{O}$ (0.5), $\mathrm{NaCl}(0.5)$ and $\mathrm{CaCl}_{2} \cdot 2 \mathrm{H}_{2} \mathrm{O}(0.5)$ was inoculated with $24 \mathrm{~h}$ old inoculum $(2 \%, \mathrm{v} / \mathrm{v})$ of wild type as well as mutant cultures. The $\mathrm{pH}$ of the growth medium was adjusted at 10 with $1 \mathrm{~N} \mathrm{HCl} /$ $\mathrm{NaOH}$ before sterilization at $121^{\circ} \mathrm{C}$ for $15 \mathrm{~min}$. The inoculated growth broths were incubated at $37^{\circ} \mathrm{C}$ for $24 \mathrm{~h}$ in water bath shaker (Eyela, Japan) with agitation speed of $140 \mathrm{rpm}$. After that the fermented broth was centrifuged at $9000 \times \mathrm{x}$ at $4^{\circ} \mathrm{C}$ for $10 \mathrm{~min}$ to get the clear enzyme solution.

\section{Determination of kinetic parameters}

Different kinetic parameters for biomass and enzyme yield were determined according to the methods described by Pirt (1975) and Okpokwasili and Nweke (2005). All these kinetic parameters viz. $\mathrm{Y}_{\mathrm{p} / \mathrm{s}}, \mathrm{Y}_{\mathrm{p} / \mathrm{x}}, \mathrm{Y}_{\mathrm{x} / \mathrm{s}}, \mathrm{u}\left(\mathrm{h}^{-1}\right), \mathrm{q}_{\mathrm{s}}, \mathrm{Q}_{\mathrm{s}}, \mathrm{q}_{\mathrm{p}}$ and $\mathrm{Q}_{\mathrm{p}}$ were studied at pre-optimized culture conditions in batch fermentation process.

\section{Total Viable count}

Total viable count after proper dilution was determined according to the method illustrated by Eaten et al. (2005).

\section{Estimation of dry cell biomass}

The biomass contents were determined by measuring the dry weight from a known amount of sample centrifuged at $9000 \mathrm{x} g$ for $10 \mathrm{~min}$ at $4^{\circ} \mathrm{C}$ and the cell pellet was washed three times with normal saline to remove the suspended particles. The washed sample was then dried at $105^{\circ} \mathrm{C}$ till the constant weight was obtained.

\section{Analytical procedures}

Determination of proteolytic activity

Alkaline protease activity was determined by using $1.0 \%(\mathrm{w} / \mathrm{v})$ casein solution as a substrate in $0.05 \mathrm{M}$ glycine- $\mathrm{NaOH}$ buffer at $\mathrm{pH} 11.0$ (Yang and Huang, 1994). The substrate was treated with a known amount of enzyme solution for $15 \mathrm{~min}$ at $60^{\circ} \mathrm{C}$. One proteolytic unit (PU) was defined as amount of the enzyme that released $1 \mathrm{ug}$ of tyrosine $/ \mathrm{mL} / \mathrm{min}$ under the assay conditions.

\section{Estimation of extracellular protein contents}

The total protein contents of the samples were determined by the method of Lowry using bovine serum albumin (BSA) as a reference standard (Lowry et al., 1951).

\section{Estimation of Glucose contents}

Glucose contents were determined according to the phenol-sulfuric acid method described by Dubois et al. (1956).

\section{Application of alkaline protease as a dehairing agent}

Dehairing property of alkaline protease was observed by a slightly modified method of Wang et al. (2007). Salted goat skin was obtained from local market, washed and cut into different small pieces $\left(5 \times 5 \mathrm{~cm}^{2}\right.$ sizes). These pieces were soaked in alkaline protease produced by mutant $B$. licheniformis UV-9 and incubated at $40^{\circ} \mathrm{C}$ in water bath shaker with agitation speed of $100 \mathrm{rpm}$ for different time periods (3-15 h). After required period, the skin pieces were gently scrapped with fingers to remove the loose hairs because the mechanical treatment at the laboratory scale was not as vigorous as in industrial drums. The dehairing efficacy was assessed according to the depilated area of the skin at various time intervals and the quality of the dehaired skin was estimated according the physical appearance observed by naked eyes. The dehaired skin with high quality showed clear hair pore, clear grain structure and no collagen damage.

\section{Chemicals and Statistical analysis}

All the chemicals used in this study were of analytical grade. Each experiment was carried out independently in triplicates in $250 \mathrm{~mL}$ Erlenmeyer flasks and the standard deviation (SD) was calculated by using Microsoft Excel Program. 


\section{RESULT AND DISCUSSION}

Effect of different mutagens on survivability of B. licheniformis $\mathrm{N}-2$

The mutation and screening of commercially viable microorganisms are important for the successful development of various strains required in the fermentation industry. Therefore, the parent strain $B$. licheniformis $\mathrm{N}-2$ was treated with different mutagens like UV irradiation, NTG $(\mathrm{N}$ methyl- $N$-nitro- $N$-nitrosoguinidine) and MMS (methyl methane sulphonate) to improve its productivity. In case of UV irradiation treatment, $32.80 \%$ survival rate was obtained after $15 \mathrm{~min}$ exposure which decreased gradually with the increase of exposure time and became $0 \%$ after exposure of $120 \mathrm{~min}$ (Table 1). Similarly, the culture of $B$. licheniformis $\mathrm{N}-2$ was treated with NTG and MMS at concentrations of $1 \mathrm{mg} / \mathrm{mL}$ and $100 \mathrm{uL} / \mathrm{mL}$, respectively. Survival rate of $0.12 \%$ was examined with NTG at $1 \mathrm{mg} / \mathrm{mL}$ concentration after an exposure of $120 \mathrm{~min}$ (Table 2).

Table 1 - Survival data for B. licheniformis N-2 after UV irradiations treatment for different time intervals.

\begin{tabular}{ccc}
\hline UV Exposure time (min) & $\begin{array}{c}\text { No of colonies germinated after } \\
\text { UV exposure at } \mathbf{2 5 4} \mathbf{~ n m}\end{array}$ & Survival rate (\%) \\
\hline 0 & 1768 & 100 \\
15 & 580 & 32.80 \\
30 & 326 & 18.44 \\
45 & 77 & 4.36 \\
60 & 12 & 0.67 \\
90 & 2 & 0.11 \\
120 & 0 & 0.00 \\
\hline
\end{tabular}

Survival rate was calculated as follows:

Survival rate $(\%)=100 x$ (Colony count after exposure time $\mathrm{t}) / 1768$.

Table 2 - Survival data for B. licheniformis N-2 after NTG treatment for different time intervals.

\begin{tabular}{ccc}
\hline NTG Exposure time (min) & $\begin{array}{c}\text { No of colonies germinated after } \\
\text { NTG treatment at conc. } \mathbf{~ m g / m L}\end{array}$ & $\begin{array}{c}\text { Survival rate } \\
(\%)\end{array}$ \\
\hline 0 & 1696 & 100 \\
15 & 476 & 28.07 \\
30 & 201 & 11.85 \\
45 & 90 & 5.31 \\
60 & 26 & 1.53 \\
90 & 9 & 0.45 \\
120 & 2 & 0.12 \\
\hline
\end{tabular}

Survival rate was calculated as follows:

Survival rate $(\%)=100 x($ Colony count after time $\mathrm{t}) / 1696$

The survival rate with MMS at $100 \mathrm{ug} / \mathrm{mL}$ concentration for same exposure time was $0 \%$ (Table 3). Similar trend of decrease in survivability with increase in exposure time has also been reported by some other investigators (Meraz et al., 2005; Dutta et al., 2006). UV irradiation and MMS mutagen were found more affective against $B$. licheniformis $\mathrm{N}-2$ culture as compared to NTG. The desirable mutants of $B$. subtilis for enzyme production after MNNG treatment have been demonstrated in an earlier investigation (Cheng-gang et al., 2008). All these findings indicated that the survivability of parent strain depended on the nature of the microorganism, treatment period and the type of mutagens.

\section{Selection of hyper-proteolytic mutant}

From UV treated plates, 14 mutants of 60 and 90 min exposures were selected for screening on skim milk agar plates. Similarly, 11 and 14 mutants from NTG and MMS treatments, respectively were selected for visualizing the efficiency of their extracellular protease. Nine hyper-proteolytic 
mutants ( 3 from each mutagenic treatment) known as positive mutants were primarily selected on the basis of zone of clearance on skim milk agar plates (Table 4).

Table 3 - Survival data for B. licheniformis N-2 after MMS treatment for different time intervals.

\begin{tabular}{ccc}
\hline MMS Exposure time (min) & $\begin{array}{c}\text { No of colonies germinated after } \\
\text { MMS treatment at conc. 100 } \\
\mathbf{u L / m L}\end{array}$ & $\begin{array}{c}\text { Survival rate } \\
(\boldsymbol{\%})\end{array}$ \\
\hline 0 & 1752 & 100 \\
15 & 524 & 29.91 \\
30 & 291 & 16.61 \\
45 & 67 & 3.82 \\
60 & 13 & 0.74 \\
90 & 1 & 0.06 \\
120 & 0 & 0.00 \\
\hline
\end{tabular}

Survival rate was calculated as follows:

Survival rate $(\%)=100 x$ (Colony count after time $\mathrm{t}) / 1752$

Table 4 - Estimation of zone of clearance on skim milk agar plates produced by mutants and parent strain after $24 \mathrm{~h}$ incubation at $37^{\circ} \mathrm{C}$.

\begin{tabular}{lc} 
Bacillus strains & $\begin{array}{c}\text { Zone of clearance } \\
(\mathbf{m m})\end{array}$ \\
\hline Parent & 26 \\
\hline UV- mutants & 38 \\
UV-4 & 44 \\
UV-9 & 40 \\
UV-13 & \\
NTG-mutants & 28 \\
NTG -2 & 32 \\
NTG -9 & 31 \\
NTG -10 & \\
MMS-mutants & 38 \\
MMS-1 & 28 \\
MMS-4 & 42 \\
\hline
\end{tabular}

UV: Ultra violet. NTG: N-methyl-N-nitro-N-nitrosoguinidine. MMS: Methyl methane sulfonate

These mutants were further evaluated through shake flask enzyme production studies at preoptimized culture conditions over the parent strain of B. licheniformis N-2. Among these, the maximum alkaline protease production (1384 $\mathrm{PU} / \mathrm{mL}$ ) was observed for the mutant UV-9 followed by MMS-14 and UV-13, producing 1280 and $1260 \mathrm{PU} / \mathrm{mL}$ alkaline protease, respectively (Table 5). The results showed that the UV-9 was the most hyper-active mutant, giving approximately 1.4 fold more alkaline protease over the parent strain $(991 \mathrm{PU} / \mathrm{mL}$ ) in similar culture conditions. Shikha et al. (2007) reported 1.44 fold increase in alkaline production over the parent strain of B. pantotheneticus. Dutta and Banerjee (2006) observed 2.5 fold increased in alkaline protease production by UV mutant Pseudomonas sp. JNGR242. Rao et al. (1998) reported that mutagenesis either by conventional methods or by recombinant-DNA technology played an important role in improving the yield of protease. It was also observed that the mutagenic treatment also affected the shapes and sizes of the mutants colonies. Almost half of the colonies showed flat growth pattern with smooth outline on skim milk agar plates while the remaining colonies showed small, dense and wrinkle growth. The smaller colony sizes suggested repression in growth of 
mutants. The difference in colony size could also be attributed to other mutations or structural defects in other enzymes, such as fatty acid synthetase as described by Zhang and Yoshiyuki, (1993). The results of present study illustrated that the dense and wrinkled mutant usually gave higher yield of protease as shown by zone of clearance Fig. 1. Nehete et al. (1985) reported similar observations that rough and wrinkled $B$. licheniformis mutants produced higher yield of alkaline protease.

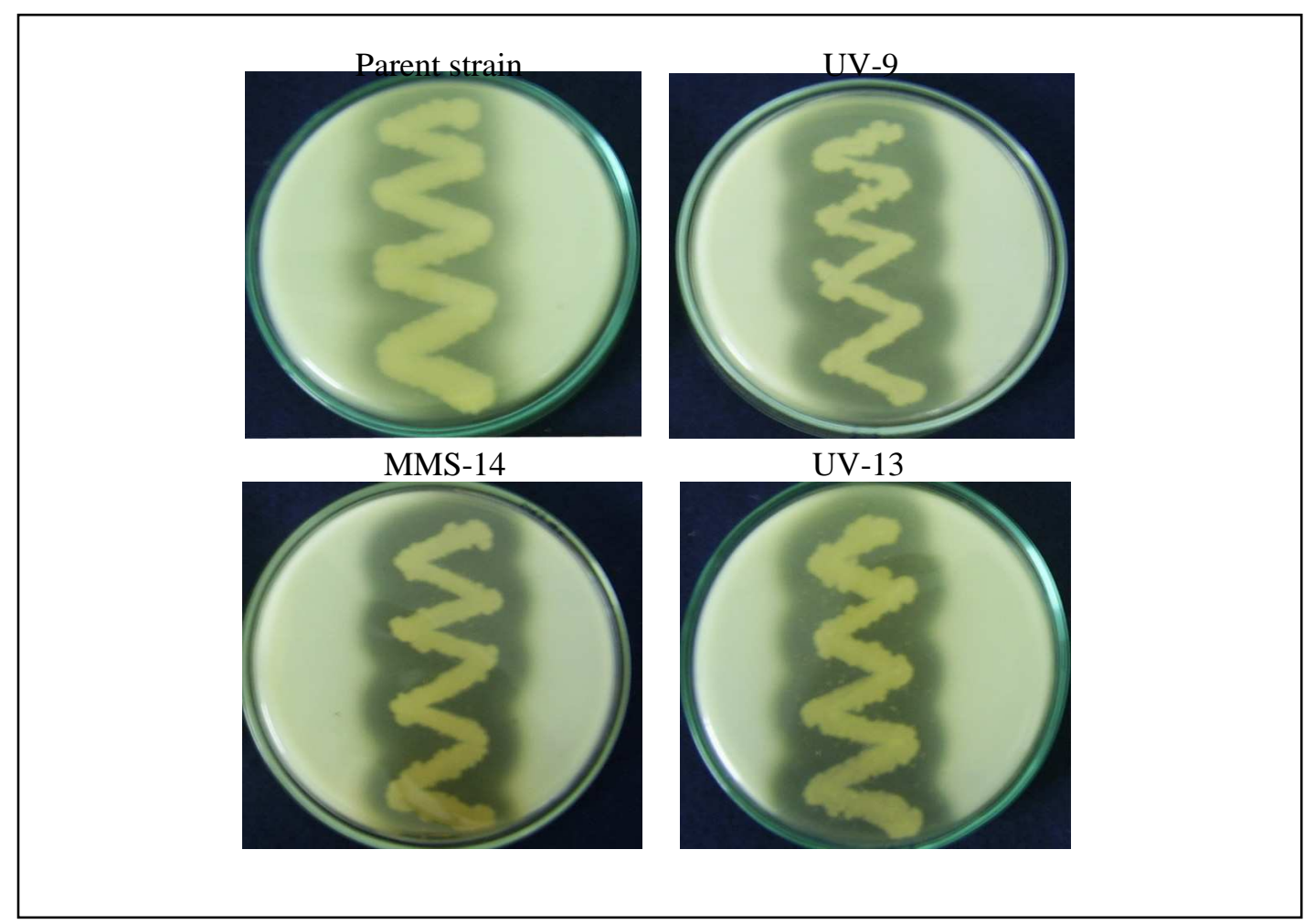

Figure 1 - The zones of clearance on skim mild agar plates produced by parent strain $B$. licheniformis $\mathrm{N}-2$ and its various mutants after incubation at $37^{\circ} \mathrm{C}$ for $24 \mathrm{~h}$

The mutant UV-9 also showed enhanced alkaline protease productivity in term of yield coefficients (Table 5). The yield coefficients $\mathrm{Y}_{\mathrm{p} / \mathrm{s}}(201 \mathrm{PU} / \mathrm{g}$ glucose consumed) and $\mathrm{Y}_{\mathrm{p} / \mathrm{x}}(393 \mathrm{PU} / \mathrm{g}$ of cell biomass formed) of mutant UV-9 was found much improved as compared to the parent strain and the rest of mutants. These findings indicated that mutation by UV irradiations played an important role in strain improvement for commercial exploitation and the mutant UV-9 was selected as a best positive mutant for alkaline protease production after the intensive screening studies.
Comparative analysis of glucose consumption by parent strain and UV-9 in submerged batch fermentation process

The cost of the enzyme is a major obstacle for its production and application at commercial scale. Therefore, the microorganisms with high yield of protease and less consumption of metabolizable sugar are a vital choice for the enzyme production at commercial scale.

To analyze the glucose consumption and protease production, batch fermentation was carried out in shake flasks cultures and the samples were collected up to $48 \mathrm{~h}$ with a constant interval of $4 \mathrm{~h}$. 
Table 5 - Comparison of alkaline protease productivity among parent strain of $B$. licheniformis N-2 and selected mutants in shake flask study

\begin{tabular}{|c|c|c|c|c|c|c|c|}
\hline \multirow{2}{*}{$\begin{array}{l}\text { Bacillus } \\
\text { strains }\end{array}$} & \multirow{2}{*}{$\begin{array}{c}\text { Cell biomas } \\
(\mathrm{g} / \mathrm{L})\end{array}$} & \multirow{2}{*}{$\begin{array}{c}\text { Substrate } \\
\text { consumed } \\
(\mathrm{g} / \mathrm{L})\end{array}$} & \multirow{2}{*}{$\begin{array}{c}\text { Total } \\
\text { Protein } \\
(\mathrm{mg} / \mathrm{mL}) \\
\end{array}$} & \multirow{2}{*}{$\begin{array}{c}\text { Protease } \\
\text { activity } \\
(\text { PU/mL) }\end{array}$} & \multicolumn{3}{|c|}{ Alkaline protease production parameters } \\
\hline & & & & & $\mathbf{Y}_{\mathrm{p} / \mathrm{s}, \mathbf{1 0 0 0}}$ & $\mathbf{Y}_{\mathrm{p} / \mathbf{x}, \mathbf{1 0 0 0}}$ & $\mathbf{Y}_{\mathrm{x} / \mathrm{s}}$ \\
\hline Parent & $3.85 \pm 0.11$ & $10 \pm 0.00$ & $3.68 \pm 0.07$ & $991.23 \pm 25.07$ & 99.12 & 257.46 & 0.385 \\
\hline \multicolumn{8}{|l|}{$\begin{array}{l}\text { UV- } \\
\text { mutants }\end{array}$} \\
\hline UV-4 & $4.45 \pm 0.12$ & $10 \pm 0.00$ & $4.11 \pm 0.16$ & $1122.38 \pm 23.55$ & 112.23 & 252.22 & 0.455 \\
\hline UV-9 & $3.52 \pm 0.10$ & $6.86 \pm 0.23$ & $3.95 \pm .13$ & $1384.22 \pm 19.85$ & 201.19 & 393.24 & 0.512 \\
\hline UV-13 & $4.23 \pm 0.17$ & $10 \pm 0.00$ & $4.76 \pm 0.18$ & $1260.67 \pm 18.12$ & 126.06 & 298.03 & 0.423 \\
\hline \multicolumn{8}{|l|}{$\begin{array}{l}\text { NTG- } \\
\text { mutants }\end{array}$} \\
\hline NTG -2 & $3.93 \pm 0.08$ & $8.57 \pm 0.30$ & $4.28 \pm 0.12$ & $1055.26 \pm 15.73$ & 123.13 & 268.51 & 0.459 \\
\hline NTG -9 & $3.24 \pm 0.11$ & $10 \pm 0.00$ & $3.77 \pm 0.15$ & $1093.15 \pm 26.33$ & 109.31 & 337.39 & 0.324 \\
\hline NTG -10 & $3.45 \pm 0.05$ & $10 \pm 0.00$ & $3.33 \pm 0.13$ & $1075.45 \pm 21.18$ & 107.54 & 311.73 & 0.345 \\
\hline \multicolumn{8}{|l|}{$\begin{array}{l}\text { MMS- } \\
\text { mutants }\end{array}$} \\
\hline MMS-1 & $4.38 \pm 0.10$ & $8.67 \pm 0.35$ & $4.08 \pm 0.17$ & $1180.92 \pm 31.12$ & 136.21 & 269.62 & 0.505 \\
\hline MMS-4 & $3.78 \pm 0.13$ & $9.04 \pm 0.15$ & $3.91 \pm 0.11$ & $1125.48 \pm 20.57$ & 124.50 & 297.75 & 0.418 \\
\hline MMS-14 & $4.02 \pm 0.11$ & $10 \pm 0.00$ & $3.97 \pm 0.14$ & $1280.58 \pm 25.18$ & 128.06 & 318.55 & 0.402 \\
\hline
\end{tabular}

The cultivations were performed in a basal medium containing $1 \%(\mathrm{w} / \mathrm{v})$ glucose conc. at initial $\mathrm{pH} 10$ and incubation temperature $37^{\circ} \mathrm{C}$ for $24 \mathrm{~h}$ with agitation speed of $140 \mathrm{rpm}$. $\mathrm{Y}_{\mathrm{p} / \mathrm{s}}$ : Enzyme produced/g glucose consumed; $\mathrm{Y}_{\mathrm{p} / \mathrm{x}}$ : Enzyme produced/g cells formed; $\mathrm{Y}_{\mathrm{x} / \mathrm{s}}: \mathrm{g}$ cells/g glucose consumed; date are the mean of three independent replicates \pm standard deviation

Maximum yield of alkaline protease (1384 $\mathrm{PU} / \mathrm{mL}$ ) was obtained by the mutant UV-9 after 24 $\mathrm{h}$ even when $3.14 \mathrm{~g} / \mathrm{L}$ glucose remained in the medium (Fig. 2). The wild type strain utilized glucose faster than the mutant and consumed almost complete glucose $(9.98 \mathrm{~g} / \mathrm{L})$ and gave maximum yield of alkaline protease $(991 \mathrm{PU} / \mathrm{mL}$ ) after $24 \mathrm{~h}$ of incubation. These findings indicated that UV-9 mutant produced 1.4 fold more alkaline protease over the parent strain at $24 \mathrm{~h}$ of incubation. However, the similar pattern of reduction in enzyme production was observed in both UV-9 mutant and wild type $B$. licheniformis $\mathrm{N}-2$ after $24 \mathrm{~h}$ incubation. Higher cell biomass $(3.84 \mathrm{~g} / \mathrm{L})$ was observed in case of wild type than mutant UV-9 that might be due to rapid consumption of glucose. The consumption rate of glucose by UV-9 mutant was observed very slow and $2.65 \mathrm{~g} / \mathrm{L}$ still remained in the growth medium after $48 \mathrm{~h}$ of fermentation, indicating that UV-9 mutant might be insensitive to catabolite repression. Sunitha et al. (1999) reported similar pattern of glucose consumption for alkaline protease biosynthesis by a mutant strain of Thermoactinomyces sp. E 79. Bierbaum et al. (1994) also used UV-mutation approach for $B$. licheniformis to improve the yield of alkaline protease and make the microorganism insensitive to catabolite repression.

During kinetic studies, the values of substrates consumption rates $\left(\mathrm{q}_{\mathrm{s}}\right.$ and $\left.\mathrm{Q}_{\mathrm{s}}\right)$ were found higher in case of parent strain, indicating more consumption of substrate for its growth as compared to the mutant UV-9 (Table 6). On the other hand, the values of product formation parameters $\left(\mathrm{q}_{\mathrm{p}}\right.$ and $\left.\mathrm{Q}_{\mathrm{p}}\right)$ were found higher in case of mutant UV-9. These results revealed that the higher productivity rate of UV-9 with less substrate consumption could make the process of alkaline protease production economically more feasible for the mutant UV-9 over the parent strain.

\section{Application of alkaline protease as a dehairing agent}

The enzymatic dehairing on industrial scale is generally accompanied by the use of small amount of lime to improve the dehairing efficacy and to reduce the cost of the dehairing process (Thanikaivelan et al., 2004). The utilization of lime has a lot of environmental hazards. Therefore, the dehairing employing solely protease is more environmental friendly and can be easily controlled due to single component treatment. 
Complete removal of hairs has been achieved through an enzyme without chemical assistance (Thangam et al., 2001; Dayanandan et al., 2003; Macedo et al., 2005). The alkaline protease produced by UV-9 was used as a dehairing agent by applying it on the different pieces of goat skin to exploit its commercial significance. A complete dehairing of skin with clean hair pore and clean grain structure was observed after $12 \mathrm{~h}$ of treatment (Fig. 3).
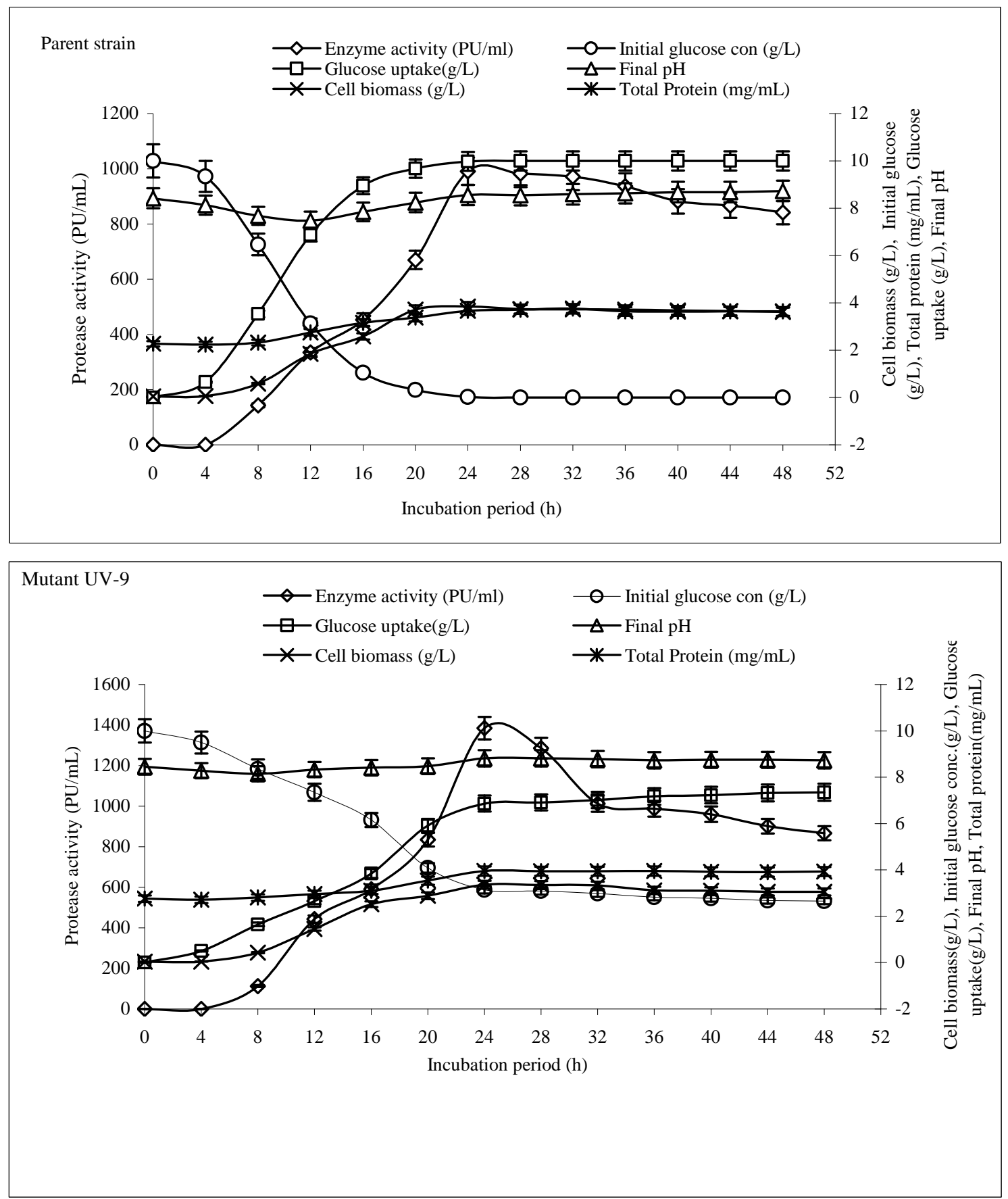

Figure 2 - Comparative study of glucose consumption and protease production by parent strain B. licheniformis $\mathrm{N}-2$ and its best proteolytic mutant UV-9 in the growth medium by submerged batch fermentation process. 
Table 6 - Comparison of kinetic parameters for alkaline protease production by parent strain of $B$. licheniformis $\mathrm{N}-2$ and its best mutant UV-9

\begin{tabular}{lcc}
\hline Kinetic parameters & Parent strain & Mutant UV-9 \\
\hline Substrate consumption parameters & & \\
$\mu\left(\mathrm{h}^{-1}\right)$ & 0.180 & 0.185 \\
$\mathrm{q}_{\mathrm{s}}(\mathrm{g} / \mathrm{g} / \mathrm{h})$ & 0.108 & 0.085 \\
$\mathrm{Q}_{\mathrm{s}}(\mathrm{g} / \mathrm{L} / \mathrm{h})$ & 0.416 & 0.286 \\
\hline Product formation parameters & & \\
$\mathrm{q}_{\mathrm{p}, 1000}$ (Product/g/h) & 1.0753 & 17.165 \\
$\mathrm{Q}_{\mathrm{p}, 1000}$ (Product/L/h) & 41.293 & 57.676 \\
\hline
\end{tabular}

Kinetic parameters: $\mu\left(\mathrm{h}^{-1}\right)$ : Specific growth rate; $\mathrm{q}_{\mathrm{s}}\left(\mathrm{g} / \mathrm{g}\right.$ cells/h): g glucose consumed/g cells/h; $\mathrm{Q}_{\mathrm{s}}(\mathrm{g} / \mathrm{L} / \mathrm{h}): \mathrm{g}$ glucose consumed/L/h; $\mathrm{q}_{\mathrm{p}}$ (Product/g/h): Enzyme produced/g cells/h; $\mathrm{Q}_{\mathrm{p}}$ (Product/L/h):Enzyme produced /L/h.

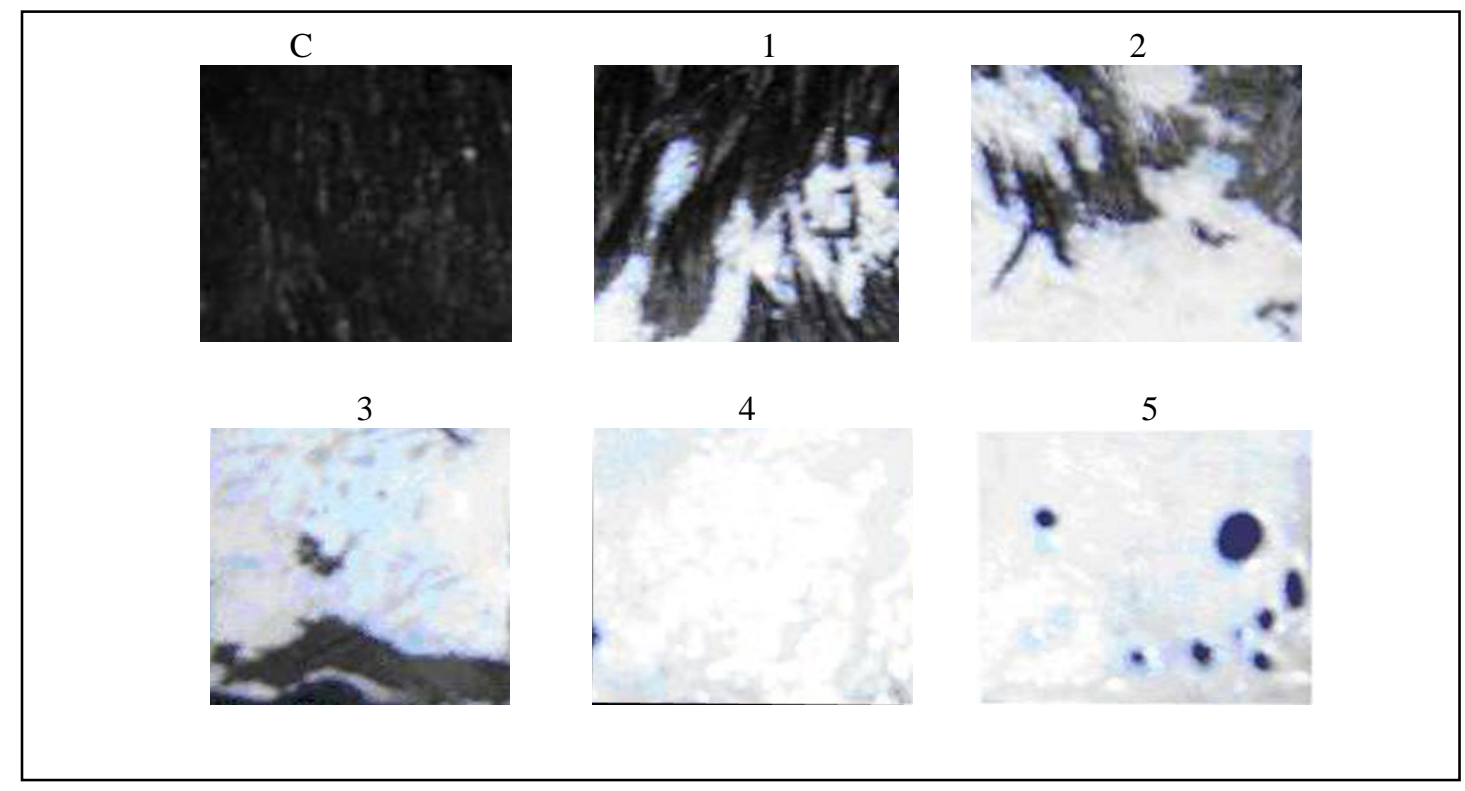

Figure 3 - Removal of hairs from goat skin pieces $\left(5 \times 5 \mathrm{~cm}^{2}\right)$ by alkaline protease produced by mutant UV-9. The skin pieces were soaked in alkaline protease broth $(1384.22 \mathrm{PU} / \mathrm{mL})$ at $40{ }^{\circ} \mathrm{C}$ for different time intervals. C: Control (without treatment); $1: 3 \mathrm{~h} ; 2: 6 \mathrm{~h} ; 3: 9 \mathrm{~h}$; 4: $12 \mathrm{~h}$ and $5: 15 \mathrm{~h}$.

The skin structure was found intact, indicating that the enzyme did not apparently destroy or modify the skin collagen structure. A further increase in treatment period up to $15 \mathrm{~h}$ created some small holes in the skin. These results suggested that identification of proper treatment or soaking period was very much essential to control the process of dehairing which alternatively affected the quality of leather and leather products. Similar findings about dehairing have also been reported with alkaline protease produced by a mutant strain of B. pumilus BA06 (Wang et al., 2007).

\section{CONCLUSION}

The cost of the enzyme in a bioprocess can be reduced by introducing hyper-productive strain after suitable mutagenic treatments. Different mutagenic treatments i.e., UV irradiation, MMS and NTG were employed on a parent strain to improve the yield of alkaline protease. All these treatments affected the morphological and physiological characteristics of mutants, for substrate consumption and product formation rates. However, the UV irradiated mutant UV-9 
was selected as a hyper-proteolytic mutant after extensive screening study. The mutant UV-9 showed a significant i.e., 1.4 fold increase in productivity over the parent strain $B$. licheniformis $\mathrm{N}-2$. Therefore, utilization of mutant UV-9 would be economically sensible for the large production of alkaline protease. The alkaline protease produced by Bacillus mutant UV-9 was also studied for its dehairing application against goat skin pieces for different soaking periods. The removal of hairs was found efficient and the quality of dehaired skin was found satisfactory after $12 \mathrm{~h}$ of treatment. These properties suggested that alkaline protease produced by mutant UV-9 had a promising potential for dehairing and could be used as an ideal dehairing agent in tanning industries.

\section{ACKNOWLEDGEMENTS}

The authors would like to thank to the Ministry of Science and Technology, Islamabad, Pakistan for providing financial assistance under the PSDPproject of allocation No. 31 to complete this research work.

\section{REFERENCES}

Eaten, A. D., Clesceri, L. S., Rice, E. W. and Greenberg, A. E. (2005), Microbiological examination. In: Standard methods for the examination of water and wastewater. $21^{\text {st }}$ edition. Published by American Public Health Association. 1015 Fifteenth Street, NW Washington, DC 200013710. pp 9-34 to 9-71.

Balasubramanian, S. and Pugalenthi, V. (2000), A comparative study of the determination of sulphide in tannery waste water by ion selective electrode (ISE) and iodometry. Water Res., 34, 4201-4206.

Bierbaum, G., Karutz, M., Botz, D. W. and Wandey, C. (1994), Production of protease with Bacillus licheniformis mutants insensitive to repression of exoenzyme biosynthesis. Appl. Microbiol. Biotechnol., 40, 611-617.

Cheng-gang, C. A. I., Bing-gang, L. O. U. and Xiaodong, Z. (2008). Keratinase production and keratin degradation by a mutant train of Bacillus subtilis. $J$. Zhejiang Uni. Sci. B., 9, 60-67.
Dayanandan, A., Kanagaraj, J., Sounderraj, L., Govindaraju, R., Rajkumar G. S., 2003. Application of an alkaline protease in leather processing: an ecofriendly approach. J. Clean prod., 11:533-536.

Dubois, M., Gilles, K. A., Hamilton, J. K., Rebers, P. A. and Smith F. (1956), Colorimetric method for determination of sugars and related substances. Anal. Chem., 28, 350-356.

Dutta, J. R. and Banerjee, R. (2006), Isolation and characterization of a newly isolated Pseudomonas mutant for protease production. Braz. arch. biol. technol., 49, 37-47.

Dutta, J. R., Nanda, R. K. and Banerjee, R. (2006), Strain improvement for tannase production from coculture of Aspergillus foetidus and Rhizopus oryzae. Biores. Technol., 97, 795-801.

Gupta, R., Beg, Q. K. and Lorenz, P. (2002), Bacterial alkaline protease: molecular approaches and industrial applications. Appl. Microbiol. Biotechnol., 59, 15-32.

Huang, Q., Peng, Y., Li, X., Way, H. and Zhang, Y. (2003). Purification and characterization of an extracellular alkaline serine protease with dehairing function for Bacillus pumilus. Curr. Microbiol., 46, 169-173.

Lowry, O. H., Roserbrough, N. J., Farr, A. L. and Randall, R. (1951), Protein measurement with Folin Phenol Reagent, J. Biological Chem., 193, 265-275.

Macedo, A. J., Da-silva, W. O., Gava, R., Driemeier, D. D., Henriques, J. A. and Termignoni, C. (2005). Novel keratinase from Bacillus subtilis S14 exhibiting remarkable dehairing capabilities. Appl. Environ. Microbiol., 71, 594-596.

Meraz, I. M., Choudhury T. and Hoq, M. M. (2006), Optimization of mutation conditions of Bacillus sp. to increase the yield of alkaline protease. J. Human Life Sci., 4, 43-50.

Nadeem, M, Qazi, J. I., Baig, S. J. and Syed, Q. A. (2007), Studies on commercially important alkaline protease from Bacillus licheniformis $\mathrm{N}-2$ isolated from decaying organic soil. Turk J. Biochem., 32, 171-177.

Nadeem, M., Baig, S. J., Syed, Q. A. and Qazi, J. I. (2006), Microbial production of alkaline proteases by locally isolated Bacillus subtilis PCSIR-5. Pak. J. Zool., 38, 109-114.

Nehete, P. N., Shah, V. D., and Kothari, R. M. (1985), Profile of alkaline protease production as a function of composition of the slant, age, transfer and isolate number and physiological state of cultures. Biotechnol. Lett., 7, 413-418.

Okpokwasili, G. C. and Nweke, C. O. (2005), Microbial growth substrate utilization kinetics. African $J$. Biotechnol., 5, 305-317. 
Pirt, S. J. (1975), Principles of Microbes and cell cultivation. In: Parameters of growth and analysis of growth data. Blackwell Scientific Publications, 85 Marylebone High Street London, pp. 4-14.

Puri, S., Beg, Q. K. and Gupta R. (2002). Optimization of alkaline protease production from Bacillus species by response surface methodology. Curr. Microbiol., 44, 286-290.

Pvanakrishnan, R. and Dhar, S. C. (1986), Recent advances in the depletion of hides and skins. Leather Sci., 33, 177-191.

Rao, M. B., Tanksale, A. M., Ghatge, M. S. and Deshpande, V. V. (1998), Molecular and biotechnological aspects of microbial proteases. Microbiol. Molecul. Biology, 62, 597-634.

Shikha, S. A. and Darmwal, N. S. (2007), Improved production of alkaline protease from a mutant of alkalophilic Bacillus pantotheneticus using molasses as a substrate. Biores. Technol., 98, 881-885.

Sunitha, K., Park, Y. S., Oh, T. K. and Lee, J. K. (1999), Synthesis of alkaline protease by catabolite repression-resistant Thermoactinomyces sp. E79 mutant. Biotechnol. Lett., 21, 155-158.

Thangam, E. B., Nagarajan, T., Suseela, R. G. and Chandrababu, N. K. (2001), Application of alkaline protease isolated from Alcaligenes faecalis for enzymatic unhairing in tanneries. J. Ind. Leather., 37, 215-222.
Thanikaivelan, P., Rao J. R,, Nair, B. U. and Ramasami, T. (2004), Progress and recent trends in biotechnological methods for leather processing. Trends Biotechnol., 22, 181-188.

Wang, H. Y., Liu, D. M., Liu Y., Cheng, C. F., Ma, Q. Y., Huang, Q. and Zhang, Y. Z. (2007), Screening and mutagenesis of a novel Bacillus pumilus strain producing alkaline protease for dehairing. Letters Appl. Microbiol., 44, 1-6.

Yang, S. S. and Huang, C. I. (1994). Proteases production by Amylolytic fungi in solid state fermentation. J. Chinese Agri. Chem. Soc., 32, 589601.

Zhang, X. B. and Yoshiyuki, O. (1993), Anticlastogenic and bio-antimutagenic activity of cultured broth of Saccharomyces cerevisiae 28 on mutagens. Mutation Res., 300, 201-206.
Received: January 05, 2009; Revised: April 22, 2009; Accepted: January 25, 2010. 